\title{
Investigation of toxic elements in Carassius gibelio and Sinanodonta woodiana and its health risk to humans
}

\author{
Anandkumar Arumugam ${ }^{\mathrm{a}}$, Jian $\mathrm{Li}^{\mathrm{a}}$, Prabakaran Krishnamurthy ${ }^{\mathrm{a}}$, Zhang Xi Jia ${ }^{\mathrm{a}}$, \\ Zhanrui Leng ${ }^{\mathrm{a}}$, Nagarajan Ramasamy ${ }^{\mathrm{b}, \mathrm{c}}$, Daolin $\mathrm{Du}^{\mathrm{a}^{*}}$ \\ ${ }^{a}$ Institute of Environment and Ecology, School of Environment and Safety Engineering, Jiangsu \\ University, Zhenjiang 212013, PR China \\ ${ }^{\mathrm{b}}$ Department of Applied Geology, Faculty of Engineering and Science, Curtin University, Malaysia \\ ${ }^{c}$ Curtin Malaysia Research Institute, Curtin University, Malaysia

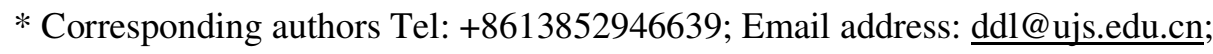 \\ anand2explore@gmail.com
}




\begin{abstract}
Increasing toxic metal content in aquatic products has become a universal burden due to the risk to aquatic organisms and human health risks associated with consumption of these products. In this study, toxic metal distribution and accumulation in the organs of fish and bivalve species of economic and culinary importance from the lower reaches of the Yangtze River are examined, and the corresponding health risks are also investigated. In general, the viscera and gill show higher concentration of metals than other tissues. The order of the accumulation sequence of metals in muscle tissue of fish and bivalve is: $\mathrm{Zn}>\mathrm{Cu}>\mathrm{Mn}>\mathrm{Cr}>$ $\mathrm{As}>\mathrm{Hg}>\mathrm{Pb}>\mathrm{Cd}$ and $\mathrm{Mn}>\mathrm{Zn}>\mathrm{Cu}>\mathrm{As}>\mathrm{Cr}>\mathrm{Pb}>\mathrm{Cd}>\mathrm{Hg}$ respectively. Maximum accumulation of $\mathrm{Mn}\left(507.50 \mu \mathrm{g} \mathrm{g}^{-1}\right)$ and $\mathrm{Pb}\left(0.51 \mu \mathrm{g} \mathrm{g}^{-1}\right)$ in the gill tissues indicates the major uptake of these metals from the water column. According to the Hazard Index (HI) calculations (based on USEPA), the analyzed metals will not cause any harmful health effects to individuals for both normal and habitual fish consumers, except for $\mathrm{Hg}$ and $\mathrm{As}$ in habitual consumers, if these species are consumed at a larger amount. Compared to the Chinese Food Health Criterion and other international standards (WHO/FAO), metal concentrations in the edible muscle tissues of the studied species are lesser than the acceptable levels and found to be fit for human consumption.
\end{abstract}

Keywords: Yangtze River, Fish, Bivalve, Risk Assessment, Arsenic, Mercury 


\section{Introduction}

One of the side effects of urbanization and industrialization is the contamination of the environment. Although toxic elements are mostly anthropogenic in origin, those originating from lithogenic processes (natural processes) also contribute to environmental contamination (Gibbs 1973; Jain 2004; Yi and Zhang 2012; Yuan et al. 2019). Sediments washed down from the catchment areas of rivers are the chief contributors of heavy metal pollutants to the oceans. There are two major ways by which the total metal concentrations in river sediment increases: the geological parent resources and climatic conditions in the river basins, and the metals added by human actions (Singh et al. 1999; Jain and Sharma 2001; Liu et al. 2019). These toxic elements finally reach the aquatic environment through runoff of river/ streams sediments where they remain as suspended particles and bounds with clay and organic matters (Prabakaran et al. 2019). Heavy metals might migrate from water and sediments into aquatic food chain, getting magnified as they move up the trophic level (Gu et al. 2015). Because of their persistence, bioavailability, recalcitrance, toxicity and biomagnification in the food chain, the contamination of the aquatic environment by metals is of great concern all over the World (Chi et al. 2007; Görür et al. 2012; Anandkumar et al. 2018).

Fish play a significant role in human diet as they are rich in protein, omega-3-fatty acids, vitamins, minerals. These nutritive qualities are important for reducing the high cholesterol levels and maintain a healthy and fit immune system (Copat et al. 2012). Fishes are at the uppermost trophic level of the aquatic food chain. As a result, they acquire a substantial quantity of toxic elements through their gill, skin, oral consumption of food and via gastrointestinal tract (Dallinger et al. 1987). Excessive contaminants in an aquatic environment would disturb the normal activities of fish, resulting in cell damage, degeneration of tissues or even death. The 
toxic elements accumulated in fish are known to cause serious health effects such as growth hindrance, deficiency in the immune system, psychosocial impairment and other illnesses associated with malfunction in humans (Iyengar and Nair 2000).

Among the aquatic organisms, fish and mussels are considered as ideal organisms for gauging pollution and possible environmental damages (Viarengo et al. 2007). Bivalves play a significant role in the aquatic food chain as they exemplify the primary consumers in the aquatic ecosystem (Hamdani and Soltani-Mazouni 2012). Mussels are mostly bottom dwellers feeding on suspended substances and plankton in the water. They have direct contact with polluted water and sediments, which makes them susceptible towards accrual of toxic elements in their soft tissues (Sarma et al. 2013). Thus, mussels are used as sensitive indicators for chemical pollution in freshwater bodies. The accumulation of toxic metals in aquatic organisms depends on the hydrodynamics of the environment, metal bioavailability, feeding nature, exposure frequency, species size, gender and reproductive cycle of the organisms (Euszczek-Trojnar et al. 2013).

The culture and capture fishery products are widely consumed all over China and are also exported to various countries (Yi et al. 2017). In 2010, China was the major producer and exporter of fish produces at the global level, accounting for 35\% of fish production (FAO 2012). In 2015, China (mainland only) produced 65.2 million tonnes of food fish, with 47.6 million tonnes (73 percent) from aquaculture and 17.6 million tonnes (27 percent) from capture. The Yangtze River has a highly diverse freshwater fish community, with 361 fish species from 29 families and 131 genera, accounting for $36 \%$ of all freshwater fish species in China (Fu et al. 2003). However, increased industrialization, urbanization and other anthropogenic activities including dumping of municipal and sewage wastes have escalated pollution levels in the middle and lower reaches of the Yangtze River (Yi et al. 2011). This has led to damages to the aquatic 
organisms residing in both freshwater and coastal ecosystems of China (Liu et al. 2010; Jia et al. 2018). Therefore, we believe that determining toxic metal accumulation in tissues of aquatic organisms will in turn help us understand the concentration of contaminants in water and their accumulation in the food web. Due to the abundant availability of aquatic products in the middle and lower reaches of the Yangtze River, the intensity of consuming these products is rapidly increasing. However, the toxic metal contents in commonly consuming fish and other aquatic products (bivalves) collected from the Zhenjiang city, lower reaches of the Yangtze River are still unknown and the information available is sparse

The objectives of this study is to investigate i) the distribution of selected metal in the different tissue organs of fish and bivalve species that are commonly consumed by the local population of Zhenjiang city in the lower reaches of the Yangtze River Delta, and ii) to evaluate the health risks associated with the consumption of fish and bivalve species.

\section{Materials and Methods}

\subsection{Study Area}

Zhenjiang city is located on the southern banks of the Yangtze River Delta (YRD) in the eastern China of Jiangsu Province, where the famous Yangtze River and Beijing-Hangzhou Grand Canal intersect. The Yangtze River is the $3^{\text {rd }}$ largest in the World and the longest river (length $6300 \mathrm{~km}$ ), in China, covering an area of $\sim 1,800,000 \mathrm{~km}^{2}$. It has 996 billion cubic meters of total water resources and delivers $>470 \mathrm{Mt}$ of sediment annually into its estuary, thus and building one of the largest deltaic system (Yi et al. 2011). Based on the topographic and hydrologic characteristics, the Yangtze River is classified into three reaches as upper (from the source to Yichang in Hubei Province; $4510 \mathrm{~km}$ length), middle (from Yichang to Hukou in 
Jiangxi Province; 940 kms) and lower (downstream from Hukou; $850 \mathrm{kms}$ ) reaches. The middle and lower reaches of the Yangtze River are characterized by Paleozoic marine sedimentary rocks and Quaternary unconsolidated sediments. The major mineral resources associated with the regional geology are $\mathrm{Cu}, \mathrm{Zn}$ and $\mathrm{Pb}$ (Wang et al. 2018). The middle and lower reaches of the river are a highly urbanized and densely populated with around 400 million inhabitants (Yang et al. 2006; Zeng and Wu 2013). The Yangtze River plays an important role in China's sustainable economic and social development. According to (YRYCC 2013), the Yangtze River Delta has released $84.31 \%$ of $\mathrm{Pb}$ and $68.84 \%$ of $\mathrm{Cr}$ to the sewage during the year 2012. The majority of sewage and wastewater discharged into the Yangtze River basin are subsequently carried into the East China Sea (ECS) which particularly affect the ecology of the river and results in long term impacts on aquatic habitats and humans (Song et al. 2011; Liu et al. 2019). The Zhenjiang city is famed for various commercial and residential areas, riverside parks, industries, transportation networks and tourism sectors etc. and has an important port for navigation along the Yangtze River. The local mean annual temperature is recorded as $15.5^{\circ} \mathrm{C}$ with the maximum (July) and minimum (January) temperatures of $28^{\circ} \mathrm{C}$ and $2.7^{\circ} \mathrm{C}$ respectively.

\subsection{Sample collection and processing}

Two commercially available and most commonly consumed species, the Prussian carp (Carassius Gibelio) (Bloch, 1782) and the Chinese pond mussel (the Eastern Asiatic freshwater clam or swan-mussel), (Sinanodonta woodiana) (Rea, 1834) were collected from the local markets for the present study. The local fish market near Jiangsu University is famous for the live fishery products caught from the catchment area of the Yangtze River region (Figure. 1). Collected specimens (minimum of 30 no's) were preserved on ice bags and shifted to the laboratory for chemical analysis. The morphometric measures of the collected species were 
recorded before they were frozen for further analysis and the details are reported in (Table 1). Later, the collected samples were defrosted at normal room temperature, followed by washing with DI water. Fish samples were dissected and the muscle, gonad and gill tissues were considered for the chemical analysis. The bivalve samples were dissected and the mantle, foot muscles, gills and gonad tissues were collected for analysis. The dissected tissue materials were dried at $60^{\circ} \mathrm{C}$ to complete dryness. The exoskeletons (shells) were detached before drying. The moisture (water) content of the tissue samples was determined as the variance between the initial and dry weight. Generally, a factor 4.54 (i.e. $78 \%$ moisture) was adopted for the present study. The dried tissue samples were powdered using an agate mortar and were stored in plastic containers which were kept in the desiccator until further analysis.

\subsection{Digestion process of Aquatic Organisms}

The dried ground tissue samples (fish and bivalve samples) were homogenized thoroughly from which one gram of sample was subjected to acid digestion with $10 \mathrm{ml}$ of conc. $\mathrm{HNO}_{3}(65 \%)$ and $\mathrm{H}_{2} \mathrm{O}_{2}(30 \%)$ according to FAO methods (Daziel and Baker 1983). After digestion, the mixture was cooled and adjusted to $50 \mathrm{ml}$ in the volumetric flask with distilled water. The digested samples were analyzed in the Flame Atomic Absorption Spectrometer (FAAS) (Analytik Jena Contr AA300) for $\mathrm{Cu}, \mathrm{Zn}$ and $\mathrm{Mn}$ concentrations. $\mathrm{Cr}, \mathrm{Cd}, \mathrm{Pb}, \mathrm{Hg}$ and $\mathrm{As}$ were determined in Inductively Coupled Isotopic Mass Spectrometer (ICP-MS) (Thermo Scientific Xseries 2). In order to avoid possible impurities, all the glassware used for the experiments were drowned in diluted $\mathrm{HNO}_{3}$ for $24 \mathrm{~h}$ and rinsed with distilled water before use and analytical grade chemical reagents were used for the analysis. The equipment was standardized with working standard solutions prepared from the stock solution of metals (Shanghai Sinopharm Chemical Reagent Limited Company, Shanghai, China). A quality control 
sample was analyzed at an interval of every five samples to ensure the quality of analyses in addition to blanks and calibration standard solutions. The standard reference material (TORT-2, National Research Council, Canada) was used to validate the accuracy and precision of the analytical performance. The mean recovery rates for trace elements ranged inclusively between $97 \%$ and $115 \%$ based on certified reference material TORT-2 (NRC, Canada), and this range is within the satisfactory level of certified values.

\subsection{Estimated Daily Intake (EDI) calculation}

The EDI was determined by taking the arithmetical mean of the metals' concentration in

$\mathrm{mg} \mathrm{kg}^{-1}$ (wet weight) and per day consumption. The Chinese population has regular daily aquatic foodstuffs consumption of 32.73 g per capita per day (EFH 2013) as described by the National Bureau of Statistics of China (CSY 2016). The population in the coastal belts of China consumes $\sim 105 \mathrm{~g}$ fish and shellfishes per day (Jiang et al. 2005), which is comparable to the consumption by the people living in the Yangtze River Basin (Yi et al. 2017). The estimated daily intake of metals was estimated using the formulae given below (Song et al. 2009; Giri and Singh 2015; Ouattara et al. 2020; Anandkumar et al. 2020).

$$
\mathrm{EDI}=\frac{C_{\text {metal }} \times \text { Cons }}{B_{w}}
$$

Where, $\mathrm{C}_{\text {metal }}$ is the metal concentration in the aquatic organism $\left(\mu \mathrm{g} \mathrm{Kg}{ }^{-1}\right.$; wet weight); Cons represents the daily consumption rate (g/day; wet weight); and $B_{w}$ is the average body weight (Kg) of an individual, which is considered as $70 \mathrm{~kg}$ for Chinese adults (Liu et al. 2018).

\subsection{Human Health Risk Assessment}


The method proposed by the United States Environmental Protection Agency (USEPA 2000) was adopted for the assessment of human health risk through the consumption of studied fish species. The level of exposure resulting from oral human consumption of particular trace metals in the fish edible tissues is expressed by calculating the average daily dose (ADD; average daily intake of a specific chemical over a lifetime). It has been calculated using the following equation, which is adopted from Anandkumar et al. (2018)

$$
A D D(m g / k g / d a y)=\frac{C m * I R * E F * E D}{B W * A T}
$$

Where, $\mathrm{C}_{\mathrm{m}}$ is the mean concentration of element/metal in fish muscle (mg/kg dry wt.), IR is the rate of ingestion $(0.0312 \mathrm{~kg} /$ day for normal and $0.1424 \mathrm{~kg} /$ day for habitual fish consumers), EF is the exposure frequency (365 days/year), ED is the exposure duration over a lifetime (assumed as 70 years), BW is the body weight (assumed as $70 \mathrm{~kg}$ for normal adults), and AT is the average lifetime (70 years $\times 365$ days/year). Risk assessment was assessed by calculating the hazard index (HI), which is a non-cancer index of adverse health effects from the intake of specific trace metal contaminants in food. $\mathrm{HI}$ is expressed as the ratio of the ADD to the oral reference dose (RfD) of the trace metal according to the following equation (USEPA 2000).

$$
\text { Hazard Index }=\frac{A D D}{\text { Oral RfD }}
$$

Where oral RfD is the oral reference dose of trace metals ( $\mathrm{mg} / \mathrm{kg} /$ days) based on the safe upper level of elements oral intake for an adult human with an average body weight of $70 \mathrm{Kg}$. The oral RfD for $\mathrm{Cu}, \mathrm{Pb}, \mathrm{Zn}, \mathrm{Mn}, \mathrm{Cd}, \mathrm{Hg}, \mathrm{As}$ and $\mathrm{Cr}$ is $0.04,0.00357,0.3,0.14,0.001,0.0003,0.0003$ and $1.5 \mathrm{mg} / \mathrm{kg} /$ day, respectively (USEPA 2015). The Hazard Index (HI) values below 1.0 indicate a non-probable occurrence of adverse health effects to humans. On the contrary, if the 
calculated HI is greater than 1.0, the occurrences of adverse health effects to humans are expected.

\section{Results and Discussion}

Among the analyzed elements, $\mathrm{Zn}$ and $\mathrm{Mn}$ concentrations are recorded higher, while $\mathrm{Cd}$ and $\mathrm{Hg}$ show the lowest concentration in the muscle tissues of both fish and bivalve species. The order of elemental accumulation in various organ tissues of analyzed fish and bivalve species are presented in Table 2. The average concentration of elements in Carassius gibelio and Sinanodonta woodiana species are presented in Table 3, with the range and mean values stated for the similar species from the supplementary literature.

\subsection{Distribution of elements}

\subsubsection{Copper}

Copper is an important nutrient for aquatic biota and humans, required for normal growth and production of hemoglobin (Sivaperumal et al. 2007). However, excess intake may result in adverse health effects. In the present study, $\mathrm{Cu}$ concentration in the fish tissues varied between 2.25 and $7.01 \mu \mathrm{g} \mathrm{g}^{-1}$ with an average of $3.70 \mu \mathrm{g} \mathrm{g}^{-1}$. The maximum $\mathrm{Cu}$ concentration was observed in the viscera followed by skin, gill and muscles of Carassius gibelio species. Copper concentration in the edible muscle tissue was lower than the values reported for the same freshwater fish species from Serbia (36.19 $\mu \mathrm{g} \mathrm{g}^{-1}$; Skoric et al. 2012), Iran (7.4 $\mu \mathrm{g} \mathrm{g}^{-1}$; Ebrahimpour et al. 2011), the Luan River, China (5.07 $\mu \mathrm{g} \mathrm{g}^{-1}$; Wang et al. 2015) and the Hooghly River, India (16.22 to $47.97 \mu \mathrm{g} \mathrm{g}^{-1}$; De et al. 2010), but higher than the reported values from Huainan, China (1.14 to $1.77 \mu \mathrm{g} \mathrm{g}^{-1}$; Wang et al. 2015). The $\mathrm{Cu}$ concentration in 
Sinanodonta woodiana varied between 2.82 and $8.39 \mu \mathrm{g} \mathrm{g}^{-1}$, with the declining order as gill > gonad $>$ mantle $>$ foot muscles. The average $\mathrm{Cu}$ concentration in the bivalve tissues was lesser (4.88 $\left.\mu \mathrm{g} \mathrm{g}^{-1}\right)$, related to the values reported from Poland $\left(57.5 \mu \mathrm{g} \mathrm{g}^{-1}\right.$; Krolak and Zdanowski 2001), the Liuyang River, China (18.5 $\mu \mathrm{g} \mathrm{g}^{-1}$; Jia et al. 2018), but greater than the values specified for Anodonta cygnea muscle tissues from Iran (0.209 $\mu \mathrm{g} \mathrm{g}^{-1}$; Pourang et al. 2001).

\subsubsection{Zinc}

Generally, aquatic organisms contain a high level of $\mathrm{Zn}$ because it is one of the common elements in the Earth's crust and an important element required for normal growth, metabolism and enzymatic reactions (Casarett and Doull 1975). They have the affinity to get accrued in fatty tissues of the aquatic organisms and affect the reproductive functioning in fishes (Bhupander and Mukherjee 2011). Overexposure of Zn results in acute and chronic toxicity such as Parkinson's disease, diarrhea, anemia, damage to the pancreas and arteriosclerosis (Gorell et al. 1997; Anandkumar et al. 2017). The highest $\mathrm{Zn}$ accumulation in the present study was detected in the viscera followed by gill, skin and muscles. Zinc concentration was higher compared to other metals and a significant difference was observed in the accumulation levels in various organs of the same species. Zinc absorption in the fish tissues varied between 63.72 and $344.26 \mu \mathrm{g} \mathrm{g}^{-1}$ (average of $181.81 \mu \mathrm{g} \mathrm{g}^{-1}$ ) which was lower than the values reported from the Serbia $(286.11 \mu \mathrm{g}$ $\mathrm{g}^{-1}$; Skoric et al. 2012) and Bangladesh (42.83 to $418.00 \mu \mathrm{g} \mathrm{g}^{-1}$; Rahman et al. 2012), but higher compared to the reported values from the Luan River, China (57.4 $\mu \mathrm{g} \mathrm{g}^{-1}$; Wang et al. 2015) and Iran (19.40 $\mu_{\mathrm{g} \mathrm{g}^{-1}}$; Ebrahimpour et al. 2011). The Zn accumulation in Sinanodonta woodiana was in the range of 102.09 to $292.75 \mu \mathrm{g} \mathrm{g}^{-1}$. The maximum accumulation was recorded in gills followed by gonad $>$ mantle $>$ foot muscles. The average $\mathrm{Zn}$ concentration of the bivalve species 
was lower (183.25 $\left.\mu \mathrm{g} \mathrm{g}^{-1}\right)$, compared to the values reported from the Liuyang River, China (581.30 $\mu \mathrm{g} \mathrm{g}^{-1}$; Jia et al. 2018) and Taihu Lake, China (1252 $\mu \mathrm{g} \mathrm{g}^{-1}$; Liu et al. 2010), but higher than the values reported from Poland (119.2 $\mu \mathrm{g} \mathrm{g}^{-1}$; Krolak and Zdanowski, 2001).

\subsubsection{Manganese}

$\mathrm{Mn}$ is an element of low toxicity and has substantial biological importance in humans, plants and animals. A small amount of $\mathrm{Mn}$ is required for numerous chemical processes of cholesterol, carbohydrates and proteins in the body. Manganese is present in enzymes such as oxidoreductases, lyases, hydrolases and isomerases and involved in bone formation (Goldhaber 2003). Higher accumulation of Mn results in a lung embolism, nerve injury, bronchitis and infertilities (ATSDR 2012). When human consumption exceeds the recommended daily intake doses, it may cause health problems of the respiratory tract and nervous system (Davies and Mundalamo 2010). The highest Mn accumulation was observed in the gill tissues followed by viscera, skin and muscles. The Mn absorption in the fish tissues varied between 1.23 and 16.45 $\mu \mathrm{g} \mathrm{g}{ }^{-1}$ with an average of $7.50 \mu \mathrm{g} \mathrm{g}^{-1}$, which was lesser than the reported values from Serbia (33.86 $\mu \mathrm{g} \mathrm{g}^{-1}$; Skoric et al. 2012), Bangladesh (9.43 to $51.17 \mu \mathrm{g} \mathrm{g}^{-1}$; Rahman et al. 2012) and Nigeria (53.02 $\mu \mathrm{g} \mathrm{g}^{-1}$; Asuquo et al. 2014) but higher than the values reported from the Eastern China (0.54 $\mu \mathrm{g} \mathrm{g}^{-1}$; Zhong et al. 2018). The Mn concentration in Sinanodonta woodiana species varied between 227.90 and $507.50 \mu \mathrm{g} \mathrm{g}^{-1}$ with an average of $369.82 \mu \mathrm{g} \mathrm{g}^{-1}$. Among the analyzed elements, Mn concentration was higher in the tissues of bivalve. The maximum accumulation was recorded in gill tissues pursued by gonad, mantle and foot muscles. The average values of $\mathrm{Mn}$ in the present study were several folds lesser than the reported values from Poland $(821.5 \mu \mathrm{g}$ $\mathrm{g}^{-1}$; Krolak and Zdanowski, 2001), the Liuyang River, China (12179.42 $\mu \mathrm{g} \mathrm{g} \mathrm{g}^{-1}$; Jia et al. 2018), 
Taihu Lake, China (11886.00 $\mu \mathrm{g} \mathrm{g}^{-1}$; Liu et al. 2010) and Italy (11258.00 $\mu \mathrm{g} \mathrm{g}^{-1}$; Ravera et al. 2003).

\subsubsection{Chromium}

Chromium is available in two different forms as $\mathrm{Cr}$ (III) and $\mathrm{Cr}$ (VI) and they enter into the aquatic habitat through natural processes (mineralization of rocks and volcanic dust) and human activities (industrial effluents, mining, etc). Cr (III) is required for normal function in our diet and the other form Cr (VI) is extremely toxic to organisms and humans (Losi et al. 1994; Anandkumar et al. 2017). Chromium compounds are vital for insulin molecules to carry glucose into the cells for glycolysis (the first step in ATP production) (Malik et al. 2009). Prolonged exposure to chromium can cause stomach agitation, ulcers, contraction, cramp and even mortality (Lingard and Norseth, 1979). The highest $\mathrm{Cr}$ concentration in the fish tissues was noticed in the muscle tissues followed by viscera, skin and gill tissues. Chromium concentration in the present study was in the ranges of 0.49 to $0.95 \mu \mathrm{g} \mathrm{g}^{-1}$ with an average of $0.67 \mu \mathrm{g} \mathrm{g}^{-1}$, which was lesser compared to the reported values of freshwater fish species from Bangladesh (0.47 to $2.07 \mu \mathrm{g} \mathrm{g}^{-1}$; Rahman et al. 2012), the Hooghly River, India (ND to $3.89 \mu \mathrm{g} \mathrm{g}^{-1}$; De et al. 2012) and the Luan River, China (6.67 $\mu \mathrm{g} \mathrm{g}^{-1}$; Wang et al. 2015), but greater than the reported values from the Taihu Lake, China (0.387 $\mu \mathrm{g} \mathrm{g}^{-1}$; Chi et al. 2007). The Cr absorption in Sinanodonta woodiana ranged from 0.54 to $0.73 \mu \mathrm{g} \mathrm{g} \mathrm{g}^{-1}$ (average of $0.64 \mu \mathrm{g} \mathrm{g} \mathrm{g}^{-1}$ ). The predominant accumulation was observed in the gonadal tissue followed by the gills, mantle and foot muscles. The average $\mathrm{Cr}$ concentration in the bivalve species was lesser compared with the identical species from the Liuyang River, China (2.88 $\mu \mathrm{g} \mathrm{g}^{-1}$; Jia et al. 2018) but greater than the value reported from Italy ( $0.40 \mu \mathrm{g} \mathrm{g}^{-1}$; Ravera et al. 2003). 


\subsubsection{Cadmium}

Compared to other elements, cadmium receives special attention due to its capability of producing a chronic toxic effect even at a low concentration level. Cadmium arises from the natural and anthropogenic origin with runoff from agricultural fields, particularly from phosphate manures which dissolved in the water column and resides in the environment for longer periods (Nagarajan et al. 2014; Khan et al. 2018). Later, they may be bioaccumulated in the liver and kidney of organisms through the food chain and cause harmful health effects (Barber and Sharma 1998). Cadmium concentration in fish tissues of the present study ranged from 0.009 to $0.056 \mu \mathrm{g}$ $\mathrm{g}^{-1}$ with an average of $0.021 \mu \mathrm{g} \mathrm{g}^{-1}$. Among the metals analyzed, Cd was the least accrued metal in the muscle tissues of Carassius gibelio species. Maximum Cd content in the fish tissues was detected in viscera followed by gill, muscle and skin tissues. The average $\mathrm{Cd}$ concentration in the current study was lesser compared with the same species from the Yangtze River, China $(0.132$ $\mu \mathrm{g} \mathrm{g}^{-1}$; Yi et al., 2011), the Hooghly River, India (0.62 to $1.20 \mu \mathrm{g} \mathrm{g}^{-1}$; De et al. 2011), Bangladesh (0.09 to $0.87 \mu \mathrm{g} \mathrm{g}^{-1}$; Rahman et al. 2012) and Nigeria (0.8 $\mu \mathrm{g} \mathrm{g}^{-1}$; Asuquo et al. 2014), but greater compared to the values reported from Huainan, China (0.005 to $0.010 \mu \mathrm{g} \mathrm{g}^{-1}$; Wang et al. 2015). The Cd concentration in Sinanodonta woodiana ranged from 0.034 to 0.135 $\mu \mathrm{g} \mathrm{g}^{-1}$ with an average of $0.094 \mu \mathrm{g} \mathrm{g}^{-1}$. The predominant accumulation was observed in the gonad followed by gill, mantle and foot muscles. The average $\mathrm{Cd}$ concentration in the muscles of bivalve was lesser than the values reported from Poland $\left(0.90 \mu \mathrm{g} \mathrm{g}^{-1}\right.$; Krolak and Zdanowski, 2001), the Liuyang River, China (0.95 $\mu \mathrm{g} \mathrm{g}^{-1}$; Jia et al. 2018), Italy (10.00 $\mu \mathrm{g} \mathrm{g}^{-1}$; Ravera et al. 2003), Austria (0.1 to $1.13 \mu \mathrm{g} \mathrm{g}^{-1}$; Gundacker 2000) but higher than that of from Korea $(0.024 \mu \mathrm{g}$ $\mathrm{g}^{-1}$; Habte et al., 2015). 


\subsubsection{Lead}

Similar to cadmium, lead is a non-essential element and a serious environmental pollutant which originates mostly from anthropogenic sources and partially from the natural sources. Dust expulsions of coal and gas-fired power stations, emission from vehicles, anti-rust agents, paints and industrial effluents are the main sources of lead pollution (Harrison and Laxen 1981; Anandkumar et al. 2017). They are non-biodegradable and have a long residence time and are toxic to biota and humans even in low concentration. Lead can cause neurotoxicity, nephrotoxicity and numerous further adverse side effects through chronic inhalation (GarcíaLestón et al. 2010). Among the analyzed elements, $\mathrm{Pb}$ was the least accumulated metal in gill tissues of fish species. Lead concentration was predominant in muscle tissues followed by viscera, skin and gill tissue. The $\mathrm{Pb}$ accretion in the present study varied between 0.003 and $0.174 \mu \mathrm{g} \mathrm{g}^{-1}$ (average of $0.121 \mu \mathrm{g} \mathrm{g}^{-1}$ ) which was lower than the reported values of freshwater fish species from Nigeria (10.01 $\mu \mathrm{g} \mathrm{g}^{-1}$; Asuquo et al. 2014), the Hooghly River, India (12.40 to 19.96 $\mu \mathrm{g} \mathrm{g}^{-1}$; De et al. 2011), Bangladesh (1.76 to $10.27 \mu \mathrm{g} \mathrm{g}^{-1}$; Rahman et al. 2012) and Huainan, China (0.12 to $0.36 \mu \mathrm{g} \mathrm{g}^{-1}$; Wang et al. 2015), and similar to that of from the Eastern China (0.12 $\mu \mathrm{g} \mathrm{g}^{-1}$; Zhong et al. 2018). The $\mathrm{Pb}$ accumulation in Sinanodonta woodiana varied from 0.278 to $0.512 \mu \mathrm{g} \mathrm{g}^{-1}$ (average of $0.390 \mu \mathrm{g} \mathrm{g}^{-1}$ ). Predominant accumulation was recorded in the gills pursued by mantle, gonad and foot muscles. The average $\mathrm{Pb}$ accumulation in the muscle tissues of bivalve was lesser compared to the reported values from Poland (49.8 $\mu \mathrm{g} \mathrm{g}^{-1}$; Krolak and Zdanowski 2001), the Liuyang River, China (5.82 $\mu \mathrm{g} \mathrm{g}^{-1}$; Jia et al. 2018), Italy (23.00 $\mu \mathrm{g} \mathrm{g}^{-1}$; Ravera et al. 2003) and Austria (0.1 to $21.30 \mu \mathrm{g} \mathrm{g}^{-1}$; Gundacker 2000) but greater than the 
average reported values from Korea $\left(0.195 \mu \mathrm{g} \mathrm{g}^{-1}\right.$; Habte et al. 2015) and Iran (0.255 $\mu \mathrm{g} \mathrm{g}^{-1}$; Pourang et al. 2010).

\subsubsection{Mercury}

Mercury is a serious environmental contaminant, toxic to aquatic biota and humans even in small quantities. Mercury is present as methylmercury $(\mathrm{MeHg}$ ) in fishery products because aquatic organisms possess an extraordinary ability to turn inorganic mercury into organic compounds (MeHg) which is easily transferable further through the aquatic food chain (Bhupander and Mukherjee 2011). Overexposure to mercury can cause neurological modifications in adults because the target organ is the brain; they have the ability to simply bypass the blood-brain and placental barriers (Diez 2009). Interestingly, higher $\mathrm{Hg}$ accumulation was observed in the muscle tissues followed by viscera, skin and gills. Mercury concentration in the fish tissues varied between 0.016 and $0.454 \mu \mathrm{g} \mathrm{g}^{-1}$ with an average of $0.201 \mu \mathrm{g} \mathrm{g}^{-1}$ which was lesser compared to the reported values from the Serbia $\left(0.79 \mu \mathrm{g} \mathrm{g}^{-1}\right.$; Skoric et al. 2012), but higher than that of from India $\left(0.14 \mu \mathrm{g} \mathrm{g}^{-1}\right.$; Malik et al. 2009). The $\mathrm{Hg}$ concentration in Sinanodonta woodiana ranged from 0.014 to $0.032 \mu \mathrm{g} \mathrm{g}^{-1}$. Among the analyzed elements, $\mathrm{Hg}$ was the least accumulated metal in tissue organs of bivalve species. The predominant accumulation was recorded in gill tissues followed by gonad, foot muscles and mantle. The average $\mathrm{Hg}$ absorption in the bivalve species was lower $\left(0.021 \mu \mathrm{g} \mathrm{g}^{-1}\right)$, than the values reported from Korea (0.052 $\mu \mathrm{g} \mathrm{g}^{-1}$; Habte et al. 2015) for the same species.

\subsubsection{Arsenic}

Arsenic prevails in both terrestrial and aquatic habitat due to natural and anthropogenic processes (Rahman et al. 2012). Though ubiquitous, it is toxic for humans and animals. The 
inorganic arsenic forms are more perilous to human than the organic ones (Bhupander and Mukherjee 2011). Chronic exposure to inorganic As may persuade various effects on the skin, cardiovascular and hematopoietic system (Jia et al. 2017). The highest accumulation in the fish tissues was observed in the muscle tissue followed by skin, viscera and gills. The concentration of As in the present study varied between 0.515 and $0.823 \mu \mathrm{g} \mathrm{g}^{-1}$ (average of $0.688 \mu \mathrm{g} \mathrm{g}^{-1}$ ), which is lower compared to the value reported for the similar species from Bangladesh (1.97 to $6.24 \mu \mathrm{g} \mathrm{g}^{-1}$; Rahman et al. 2012), but greater than that of from the Luan River $\left(0.10 \mu \mathrm{g} \mathrm{g}^{-1}\right.$; Wang et al., 2015) and Eastern China $\left(0.17 \mu \mathrm{g} \mathrm{g}^{-1}\right.$; Zhong et al. 2018) and almost identical to the values recorded from the Serbia (0.69 $\mu \mathrm{g} \mathrm{g}^{-1}$; Skoric et al. 2012). The As adsorption in Sinanodonta woodiana species ranges from 1.95 to $3.93 \mu \mathrm{g} \mathrm{g}^{-1}$ with an average of $2.90 \mu \mathrm{g} \mathrm{g}^{-1}$. The predominant accumulation was observed in gills followed by gonads, foot muscles and mantle. The observed average value of As in the present study was several folds lesser than the reported values for the same species from the Liuyang River, China (13.97 $\mu \mathrm{g} \mathrm{g}^{-1}$; Jia et al. 2018), the Taihu Lake, China (15.00 $\mu \mathrm{g} \mathrm{g}^{-1}$; Liu et al. 2010), Italy (13.00 $\mu \mathrm{g} \mathrm{g}^{-1}$; Ravera et al. 2003), and Korea (3.545 $\mu \mathrm{g} \mathrm{g}^{-1}$; Habte et al. 2015).

\subsection{Accumulation of elements in various tissue organs}

In the present study, the analyzed metals $(\mathrm{Cu}, \mathrm{Zn}, \mathrm{Mn}, \mathrm{Cr}, \mathrm{Cd}, \mathrm{Pb}, \mathrm{Hg}$, and $\mathrm{As})$ in tissue organs of Carassius gibelio and Sinanodonta woodiana species show significant variations in their accumulation pattern. Essential elements $(\mathrm{Cu}$ and $\mathrm{Zn})$ are accumulated higher in the tissue organs compared to the non-essential elements $(\mathrm{Cd}, \mathrm{Pb}, \mathrm{Hg}$, and $\mathrm{As})$. Many researchers have observed a similar accumulation pattern of higher concentration of essential elements in the tissue organs compared to the non-essential elements (Zubcov et al. 2012; Wang, Chu, et al. 
2015; Varol et al. 2017; Anandkumar et al. 2018). Among the analyzed metals in the fish species, $\mathrm{Cu}, \mathrm{Zn}$, and $\mathrm{Cd}$ show higher concentration in the viscera tissue; $\mathrm{Cr}, \mathrm{Pb}, \mathrm{Hg}$ and $\mathrm{As}$ shows higher accumulation in muscle tissue and Mn accumulated higher in the gill tissue, whereas in bivalve species accumulation of $\mathrm{Cu}, \mathrm{Zn}, \mathrm{Mn}, \mathrm{Pb}, \mathrm{Hg}$ and $\mathrm{As}$ was higher in gill tissues; $\mathrm{Cr}$ and $\mathrm{Cd}$ show higher accumulation in gonad tissue. A similar observation of high concentration of metals in viscera was detected for fish raised in polyculture systems in Hong Kong (Liang et al. 1999) and fish from the Baotou Urban section of the Yellow River (Wang et al. 2010). Moreover, higher accumulation of $\mathrm{Cd}$ in viscera compared to the other tissue of the fish is due to the presence of metallothionein proteins, which might bind certain elements such as $\mathrm{Cd}$ and $\mathrm{Cu}$ for detoxification (Ploetz et al. 2007). The high $\mathrm{Mn}$ content in the gills indicates that the metal has accumulated from the water. Another reason for the higher concentration of metals in gill tissues is due to the high density of chloride cells competent in picking up cations, such as heavy metal ions (Costa and Fernandez 2002). The accumulation pattern of Mn in the tissue organs are gills $>$ viscera $>$ skin $>$ muscle. Similar observations were also reported in Carassius auratus, Pelteobagrus fulvidraco, and Squaliobarbus curriculus collected from the Xiang River, Southern China (Jia et al. 2017). Muscle tissue is commonly considered as the organ with the low accumulation ability for toxic metals. However, this is not always the case, previous studies by Liu et al. (2015) and Jia et al. (2017) have reported the higher concentration of non-essential elements (Cr, As and $\mathrm{Cd}$ ) in the muscle tissue of S. fuscescens, P. fulvidraco and C. carassius compared to gill and liver tissues. This can be due to the distinct circulation pattern of heavy metals between various fish species (Liu et al. 2015). The obvious cause for higher metal accumulation in muscle tissue needs additional investigation. 
Elemental concentrations in different tissues of aquatic organisms (fishes and shellfish) always exhibited great variation (Fernandes et al. 2007). It is well accepted that bioaccumulation of metals by the aquatic organism depends primarily on either surrounding ambient water or from dietary exposure via food chain (levels in prey) (Terra et al. 2008). The liver is the primary organ for accumulation, metabolic processes of trace metals and detoxification with a large number of metallothioneins (MT) proteins, which are regarded as biomarkers and as cysteine bonding metals (Staniskiene et al. 2006; Huang et al. 2013). Gills are the dominant sites for metal uptake from the water column of a specific environment (Rao and Padmaja 2000). The gills filter out the metal ions from the habitual water column through the process of osmoregulation and gas exchange (Ahmed et al. 2016). When fishes and shellfishes are disclosed to high levels of contaminants in water, they naturally show greater concentrations in the gills (Reynders et al. 2008). Whereas, in the situation of metal exposure from food, metal levels in the gills are usually lesser than in other tissues (Pedlar and Klaverkamp 2002). Skin also shows higher metal accumulation when fish are exposed to higher concentrations of dissolved trace elements (Dural et al. 2007). So, the liver, intestine and gills always show higher accumulation of elements in the aquatic organisms related to the muscle tissue (Görür et al. 2012).

Carassius gibelio species have accumulated the highest levels of toxic elements (As, $\mathrm{Hg}$, $\mathrm{Cd}$, and $\mathrm{Pb}$ ) in the muscle, gill and viscera. This may be due to the omnivorous feeding performance of the fish and it mainly feeds on zooplankton, shrimp and fingerlings. They are also active swimmers that bioaccumulate and bio-magnify the toxic metals in their tissue organs (Tao et al. 2012). Freshwater mussels live in the riverbed, channels, ponds and lakes, they are microscopic plant-eating animals that suck water through a siphon and absorb the suspended particles and dissolved trace metals from the water column and accumulate in their body tissues 
(Kurnia et al. 2010). Fish living in the middle-lower layer of the water column are expected to accumulate more heavy metals compared to those fish in the surface layer of the water column (Yi et al. 2017). In the aquatic environment, sediments act as a sink for heavy metals and the level of metals is always greater in the sediments than that of in the water column. According to existing research in the Yangtze River Basin, the concentrations of heavy metals were 10010,000 times greater in the sediment than in the water column (Yi et al. 2008). Meanwhile, suspended sediments tend to adsorb heavy metals from the water and both are transported downstream, thus increasing the concentration of heavy metals in the downstream of the river (Yi et al. 2011). Aquatic organisms that reside in the bottom layers are predisposed to higher concentrations of heavy metals. The higher uptake of contaminated zoobenthic predators and other feeds infers a higher concentration of metal levels in their tissues (Yi et al., 2011). Metal accumulation in an organism is controlled by the equilibrium between uptake and elimination kinetics (Wang and Rainbow 2008). The different body parts such as muscles, gills, gonad and viscera exhibit varying metal absorption rates, which are greatly influenced by the bioavailability

of the elements in the surrounding environment, physiology, exposure frequency and feeding behavior of the organisms (Canli and Atli 2003). In addition, environmental factors such as $\mathrm{pH}$, temperature, nutrients, organic carbon, organic matter and geological processes of an ecosystem influence the bioavailability and bioaccumulation rates of elements in the aquatic organisms (Zhou et al. 2008; Rejomon et al. 2010; Rahman et al. 2012; Anandkumar et al. 2018).

\subsection{Assessment of daily intake of metals}

An assessment was made among the detected elements in the Carassius gibelio and Sinanodonta woodiana species with the mentioned values, in order to reveal the safe level of ingestion for humans. The possible threats of metals transferred to human beings are feasibly 
reliant on the number of fishery products consumed by an individual (Kamaruzzaman et al. 2010). The EDI values of studied elements are presented in Table 4. The results of the analogous EDI, achieved from the current study through the consumption of analyzed species fall below the provisional tolerable daily intake (PTDI) Joint FAO/WHO Expert Committee on Food Additives; (JECFA 1999b) except for Mn in the gill tissues of bivalve species. Therefore, the result specifies that the intake of these aquatic species on the basis of mean day-to-day exposure of the local residents is safe and does not pose any health issues.

\subsection{Human Health Risk Assessment}

Finfishes and shellfishes are the main aquatic products of the Yangtze River. Toxic metal pollution in the river must have an impact on the quality of the aquatic products. The calculated HI values of the analyzed elements in the muscle tissues and other organs of the fish and bivalve species are presented in Table 5. The determined HI values for muscle tissues of both species are $<1$ for all the analyzed elements, and will not cause any deleterious health effects at both ingestion rates on consumers except for $\mathrm{Hg}$ in fish muscle tissues and $\mathrm{Mn}$ in foot muscle tissues of bivalve species for habitual consumers and As for both ingestion rates. However, the HI values for the other tissue organs indicate that $\mathrm{Zn}, \mathrm{Mn}, \mathrm{Hg}$ and As were greater than 1, which indicates that these elements would be expected to cause non-ignorable health effects in humans when these species are consumed at a more capacity. Consequently, as far as Mn and As were concerned, restricted consumption of bivalve should be regulated or the daily consumption rate should be reduced (less than $105 \mathrm{~g}$ per day). The bivalve species should be exposed to the depuration process before consumption in order to reduce the contaminant level in their tissue organs.

\subsection{Hazard Level}


Among the studied elements, $\mathrm{As}, \mathrm{Hg}, \mathrm{Pb}$ and $\mathrm{Cd}$ are categorized as non-essential toxic elements that pose adverse health hazards to aquatic biota and humans even at trace levels. Various national and international agencies such as China's Ministry of Health, MOH (2012); FAO (1983); the WHO (1989b); the EC (2014) and the FSSAI (2015) recommend maximum tolerable guidelines for human consumption. The food criteria for aquatic animals established by these organizations are in wet weight based concentrations (Table 6). In order to compare with food quality criterions, the observed metal absorptions in the corresponding tissues of aquatic creatures in the present study (Tables 3), were transformed into wet weight by isolating the dry weight by factors ranging from 4 to 6 (Anandkumar et al. 2019). By employing this factor, the derived wet weight based concentrations of $\mathrm{As}, \mathrm{Cu}, \mathrm{Cd}, \mathrm{Cr}, \mathrm{Hg}, \mathrm{Mn}, \mathrm{Pb}$ and $\mathrm{Zn}$ in the tissue organs of Carassius gibelio and Sinanodonta woodiana species from the fresh markets of Zhenjiang City fell under the maximum permissible limits (MPLs) of the Chinese Food Health Criterion CFHC (1994), WHO (1989), FAO (1983), EC (2014) and FSSAI (2015). However, Zn, Mn and As concentration was somewhat above the tolerable level of WHO (1989) and CFHC (1994) in the other tissue organs of both species but lower in the edible muscle tissue. The high concentration of $\mathrm{Mn}$ in the gills showed that the main uptake passage of this element from the water. Identification of the explicit source of As is required, which may be either derived from the residual products used in the agricultural practices or from geological source rocks exposed in the catchment area and/or in river delta regions. However, while comparing with the Hong Kong Government regulations (1987) and the Food and Agricultural Organization (1983) Mn and As concentrations are still below the permissible limits in the consumable muscle tissues, so the investigated species in this study does not pose any biochemical hazards in their muscle tissues and harmless for consumption. 


\section{Conclusion}

The data in this paper suggests that the toxic elements in the consumable muscle tissues of Carassius gibelio and Sinanodonta woodiana species from the Zhenjiang City, the lower reaches of the Yangtze River Delta are beneath the maximum permissible limits (MPLs) of the Chinese Food Health Criterion and other international guideline values of HKG (1987), WHO (1989) and EC (2014) on wet weight basis with the exception of As and Mn in the other tissue organs. The maximum concentration of elements in fish was observed in the viscera followed by gill, skin and muscle, whereas in the bivalve, maximum concentration was recorded in the gill tissue followed by gonad, mantle and foot muscle. The metal binding proteins such as metallothioneins may play a prominent role in regulating the concentrations of metals in different tissues. A significant difference in the metal concentration was observed among the studied species and tissue organs, which is attributed to differences in the life cycle, habitat, physiology, exposure frequency and feeding behavior of the organisms. Compared to national and international standards, the elemental concentrations in the edible muscle tissue are lower than the maximum permissible limits but excessive in the other tissue organs for $\mathrm{Mn}$ and $\mathrm{Zn}$. According to the human health risk index calculations, $\mathrm{Hg}$ and As may cause non-ignorable health effects in humans if these species are consumed at a larger amount. Whereas, remaining elements will not pose any adverse health effects to humans according to the ingestion rates proposed by USEPA. Based on the calculation indices and human health point of view, the levels of $\mathrm{Mn}, \mathrm{Hg}$ and As observed in the tissue organs of studied species should be considered to be an important warning signal. Therefore, with respect to these metals, a reduced consumption rate of bivalve species is advised and the depuration process of bivalve mollusk is recommended before consumption. 


\section{Conflict of Interest Statement}

The authors state that there are no conflicts of interest.

\section{Acknowledgements}

. This research work was funded by the State Key Research Development Program of China (2017YFC1200100), the National Natural Science Foundation of China $(31570414,31800429$, 31770446), the Natural Science Foundation of Jiangsu Province (BK20170540). The first author wishes to express his gratefulness to Jiangsu University, Zhenjiang, China for the award of postdoctoral fellowship (209317). We are grateful to Dr. Merlin Franco for his valuable comments and linguistic corrections.

\section{References}

Ahmed, M., T. Ahmad, M. Liaquat, K. S. Abbasi, I. B. A. Farid, and M. Jahangir. 2016. "Tissue specific metal characterization of selected fish species in Pakistan." Environmental Monitoring and Assessment 188 (4):212. doi: 10.1007/s10661-016-5214-6.

Anandkumar, A. , R. Nagarajan, K. Prabakaran, H. B. Chua, and R. Rajaram. 2018. "Human health risk assessment and bioaccumulation of trace metals in fish species collected from the Miri coast, Sarawak, Borneo." Marine Pollution Bulletin 133:655-663. doi: https://doi.org/10.1016/j.marpolbul.2018.06.033.

Anandkumar, A., Jian Li, K. Prabakaran, Zhang Xi Jia, Zhanrui Leng, R. Nagarajan, and Daolin Du. 2020. "Accumulation of toxic elements in an invasive crayfish species (Procambarus clarkii) and its health risk assessment to humans." Journal of Food Composition and Analysis 88:103449. doi: https://doi.org/10.1016/i.jfca.2020.103449.

Anandkumar, A., R. Nagarajan, K. Prabakaran, Chua Han Bing, R. Rajaram, J. Li, and D. Du. 2019. "Bioaccumulation of trace metals in the coastal Borneo (Malaysia) and health risk assessment." Marine Pollution Bulletin 145:56-66. doi: https://doi.org/10.1016/i.marpolbul.2019.05.002.

Anandkumar, A., R. Nagarajan, K. Prabakaran, and R. Rajaram. 2017. "Trace metal dynamics and risk assessment in the commercially important marine shrimp species collected from the Miri coast, Sarawak, East Malaysia." Regional Studies in Marine Science 16:79-88. doi: https://doi.org/10.1016/j.rsma.2017.08.007.

Asuquo, F. E., I. Ewa-Oboho, E. F. Asuquo, and P. J. Udo. 2004. "Fish Species Used as Biomarker for Heavy Metal and Hydrocarbon Contamination for Cross River, Nigeria." Environmentalist 24 (1):29-37. doi: 10.1023/b:envr.0000046344.04734.39. 
ATSDR. 2012. "Toxicological Profile for Manganese. Atlanta: US Department of Health and Human Services, Public Health Service." Agency for Toxic Substances and Disease Registry. http://www.atsdr.cdc.gov/toxprofiles/tp151.pdf.

Barber, D., and M.S. Sharma. 1998. "Experimentally induced bioaccumulation and elimination of cadmium in fresh-water fishes." Pollution Research 17:99-104.

Bhupander, K., and D. P. Mukherjee. 2011. "Assessment of human health risk for arsenic, copper, nickel, mercury and zinc in fish collected from tropical wetlands in India." Advances in Life Science and Technology 2:13-24.

Canli, M., and G. Atli. 2003. "The relationships between heavy metal ( $\mathrm{Cd}, \mathrm{Cr}, \mathrm{Cu}, \mathrm{Fe}, \mathrm{Pb}, \mathrm{Zn})$ levels and the size of six Mediterranean fish species." Environmental Pollution 121 (1):129-136. doi: https://doi.org/10.1016/S0269-7491(02)00194-X.

Casarett, L. J., and J. Doull. 1975. Toxicology : The Basic Science of Poisons, fifth ed.. . USA: New York.: McGrow-Hill Company, Inc., Macmillan.

CFHC. 1994. Chinese Food Health Criterion. GB 15201-94 for Cd, GB 15199-94 for Cu, GB 14935-94 for $\mathrm{Pb}$ and GB 13106-91 for Zn. Minstry of Health of People's Republic of China.

Chi, Q., G. Zhu, and A. Langdon. 2007. "Bioaccumulation of heavy metals in fishes from Taihu Lake, China." Journal of Environmental Sciences 19 (12):1500-1504. doi: https://doi.org/10.1016/S1001-0742(07)60244-7.

Copat, C., F. Bella, M. Castaing, R. Fallico, S. Sciacca, and M. Ferrante. 2012. "Heavy Metals Concentrations in Fish from Sicily (Mediterranean Sea) and Evaluation of Possible Health Risks to Consumers." Bulletin of Environmental Contamination and Toxicology 88 (1):78-83. doi: 10.1007/s00128-011-0433-6.

Costa, O. T. F., and M. N. Fernandez. 2002. Chloride cell changes induced by nitrite exposure in an Amazonian fish species. Edited by C. Kennedy, A. Kolok and D. MacKinlay, Aquatic toxicology: mechanism and consequences. International Congress of Fish Biology. Canada.

CSY. 2016. China Statistical Yearbook. National Bureau of Statistics PRC. China Statistics Press. Beijing.

Dallinger, R., F. Prosi, H. Segner, and H. Back. 1987. "Contaminated food and uptake of heavy metals by fish: a review and a proposal for further research." Oecologia 73 (1):91-98. doi: $10.1007 /$ bf00376982.

Davies, T. C., and H. R. Mundalamo. 2010. "Environmental health impacts of dispersed mineralisation in South Africa." Journal of African Earth Sciences 58 (4):652-666. doi: https://doi.org/10.1016/i.jafrearsci.2010.08.009.

Daziel, J., and C. Baker. 1983. "Analytical methods for measuring metals by atomic absorption spectrometry." FAO Fish Tech 212:14-21.

De, T. K., M. De, S. Das, R. Ray, and P. B. Ghosh. 2010. "Level of Heavy Metals in Some Edible Marine Fishes of Mangrove Dominated Tropical Estuarine Areas of Hooghly River, North East Coast of Bay of Bengal, India." Bulletin of Environmental Contamination and Toxicology 85 (4):385-390. doi: 10.1007/s00128-010-0102-1.

Diez, S. 2009. "Human health effects of methylmercury exposure." Reviews of Environmental Contamination and Toxicology 198:111-32. doi: 10.1007/978-0-387-09647-6_3.

Dural, M., M. Z. L. Göksu, and A. A. Özak. 2007. "Investigation of heavy metal levels in economically important fish species captured from the Tuzla lagoon." Food Chemistry 102 (1):415-421. doi: https://doi.org/10.1016/i.foodchem.2006.03.001.

Ebrahimpour, M., A. Pourkhabbaz, R. Baramaki, H. Babaei, and M. Rezaei. 2011. "Bioaccumulation of Heavy Metals in Freshwater Fish Species, Anzali, Iran." Bulletin of Environmental Contamination and Toxicology 87 (4):386. doi: 10.1007/s00128-011-0376-y.

EC. 2014. Commission Regulation. No 488/2014 of 12 May 2014 Amending Regulation (EC) No 1881/2006 As Regards Maximum Levels of Cadmium in Foodstuffs. 
EFH. 2013. Exposure factors handbook of Chinese population. China Environmental Press (in Chinese). Beijing.

FAO. 1983. Compilation of Legal Limits for Hazardous Substance in Fish and Fishery Products.

FAO. 2012. Part 1: World review of fisheries and aquaculture. The state of world fisheries and aquaculture. Rome, Italy.

Fernandes, C., A. Fontaínhas-Fernandes, F. Peixoto, and M. A. Salgado. 2007. "Bioaccumulation of heavy metals in Liza saliens from the Esmoriz-Paramos coastal lagoon, Portugal." Ecotoxicology and Environmental Safety 66 (3):426-431. doi: https://doi.org/10.1016/j.ecoenv.2006.02.007.

FSSAI. 2015. Food, Safety, Standards Authority of India (FSSAI). Proposes Standard Limits of Metal Contaminants in New Food Articles.

Fu, C., J. Wu, J. Chen, Q. Wu, and G. Lei. 2003. "Freshwater fish biodiversity in the Yangtze River basin of China: patterns, threats and conservation." Biodiversity \& Conservation 12 (8):1649-1685. doi: 10.1023/A:1023697714517.

García-Lestón, J., J. Méndez, E. Pásaro, and B. Laffon. 2010. "Genotoxic effects of lead: An updated review." Environment International 36 (6):623-636. doi: https://doi.org/10.1016/i.envint.2010.04.011.

Gibbs, Ronald J. 1973. "Mechanisms of trace metal transport in rivers." Science 180 (4081):71-73.

Giri, S., and A. K. Singh. 2015. "Metals in Some Edible Fish and Shrimp Species Collected in Dry Season from Subarnarekha River, India." Bulletin of Environmental Contamination and Toxicology 95 (2):226-233. doi: 10.1007/s00128-015-1573-x.

Goldhaber, S. B. 2003 . "Trace element risk assessment: essentiality vs. toxicity." Regulatory Toxicology and Pharmacology 38 (2):232-242. doi: https://doi.org/10.1016/S0273-2300(02)00020-X.

Gorell, J. M., C. C. Johnson, B. A. Rybicki, E. L. Peterson, G. X. Kortsha, G. G. Brown, and R. J. Richardson. 1997. "Occupational exposures to metals as risk factors for Parkinson's disease." Neurology 48 (3):650-8. doi: 10.1212/wnl.48.3.650.

Görür, K. F., R. Keser, N. Akçay, and S. Dizman. 2012. "Radioactivity and heavy metal concentrations of some commercial fish species consumed in the Black Sea Region of Turkey." Chemosphere 87 (4):356-361. doi: https://doi.org/10.1016/j.chemosphere.2011.12.022.

Gu, Y. G., Q. Lin, X. H. Wang, F. Y. Du, Z. Yu, and H. H. Huang. 2015. "Heavy metal concentrations in wild fishes captured from the South China Sea and associated health risks." Marine Pollution Bulletin 96 (1):508-512. doi: https://doi.org/10.1016/j.marpolbul.2015.04.022.

Habte, G., J. Y. Choi, E. Y. Nho, S. Y. Oh, N. Khan, H. Choi, K. S. Park, and K. S. Kim. 2015. "Determination of toxic heavy metal levels in commonly consumed species of shrimp and shellfish using ICPMS/OES." Food Science and Biotechnology 24 (1):373-378. doi: 10.1007/s10068-015-0049-4.

Hamdani, A. , and N. Soltani-Mazouni. 2012. "Changes in Biochemical Composition of the Gonads of Donaxtrunculus L. (Mollusca, Bivalvia) from the Gulf of Annaba (Algeria) in Relation to Reproductive Events and Pollution." Jordan Journal of Biological Sciences 4 (3):149-156.

Harrison, R. M., and D. P. H. Laxen. 1981. "Lead pollution Causes and Control." In.: Springer, Dordrecht. HKG. 1987. Hong Kong Government. Food Adulteration (Metallic Con-tamination) Regulations. Laws of Hong Kong 2, Chapter 132.

Huang, Q., Y. Zhang, S. Liu, W. Wang, and Y. Luo. 2013. "Intraspecific Scaling of the Resting and Maximum Metabolic Rates of the Crucian Carp (Carassius auratus)." PLOS ONE 8 (12):e82837. doi: 10.1371/journal.pone.0082837.

lyengar, G. V., and P. P. Nair. 2000. "Global outlook on nutrition and the environment: meeting the challenges of the next millennium." Science of The Total Environment 249 (1):331-346. doi: https://doi.org/10.1016/S0048-9697(99)00529-X.

Jain, C. K. 2004. "Metal fractionation study on bed sediments of River Yamuna, India." Water Research 38 (3):569-578. doi: https://doi.org/10.1016/j.watres.2003.10.042. 
Jain, C. K., and M. K. Sharma. 2001. "Distribution of trace metals in the Hindon River system, India." Journal of Hydrology 253 (1):81-90. doi: https://doi.org/10.1016/S0022-1694(01)00484-X.

JECFA. 1999a. Joint FAO/WHO Expert Committee on Food Additives. Reports of the 53rd meeting of the Joint FAO/WHO Expert Committee on Food Additives (JECFA). JECFA/53/TRS. Rome, Italy: Food \& Agriculture Organisation.

JECFA. 1999b. Joint FAO/WHO Expert Committee on Food Additives. Summary and conclusions of the 53rd meeting of the Joint FAO/WHO Expert Committee on Food Additives (JECFA). JECFA/53/SC. Rome, Italy: JECFA/53/SC. Rome, Italy.

Jia, Y., L. Wang, Z. Qu, C. Wang, and Z. Yang. 2017. "Effects on heavy metal accumulation in freshwater fishes: species, tissues, and sizes." Environmental Science and Pollution Research 24 (10):93799386. doi: 10.1007/s11356-017-8606-4.

Jia, Y., L. Wang, Z. Qu, and Z. Yang. 2018. "Distribution, contamination and accumulation of heavy metals in water, sediments, and freshwater shellfish from Liuyang River, Southern China."

Environmental Science and Pollution Research 25 (7):7012-7020. doi: 10.1007/s11356-017-1068$x$.

Jiang, Q. T., T. K. M. Lee, K. Chen, H. L. Wong, J. S. Zheng, J. P. Giesy, K. K. W. Lo, N. Yamashita, and P. K. S. Lam. 2005. "Human health risk assessment of organochlorines associated with fish consumption in a coastal city in China." Environmental Pollution 136 (1):155-165. doi: https://doi.org/10.1016/i.envpol.2004.09.028.

Kamaruzzaman, B.Y., M.C. Ong, S.Z. Rina, and B. Joseph. 2010. "Levels of some heavy metals in fishes from Pahang river estuary, Pahang, Malaysia." Journal of Biological Sciences 10 (2):157-161.

Khan, M. N., M. Mobin, Z. K. Abbas, and S. A. Alamri. 2018. Fertilizers and their contaminants in soils, surface and groundwater. Edited by Dominick A., Della Sala and Michael I. Goldstein. Vol. 5, Encyclopedia of the Anthropocene: Oxford: Elsevier.

Krolak, E., and B. Zdanowski. 2001. "The Bioaccumulation of heavy metals by the mussels Anodonta woodiana (Lea 1834) and Dreissena polymorpha (Pall.) in the heated Konińskie lakes." Archives of Polish Fisheries 9 (2):229-237.

Kurnia, A. I., E. Purwanto, and E. Mahajoeno. 2010. "Exposure copper heavy metal (Cu) on freshwater mussel (Anodonta woodiana) and its relation to $\mathrm{Cu}$ and protein content in the body shell." Nusantara Bioscience 2.

Liang, Y., R. Y. H. Cheung, and M. H. Wong. 1999. "Reclamation of wastewater for polyculture of freshwater fish: bioaccumulation of trace metals in fish." Water Research 33 (11):2690-2700. doi: https://doi.org/10.1016/S0043-1354(98)00473-4.

Liu, H., G. Liu, S. Wang, C. Zhou, Z. Yuan, and C. Da. 2018. "Distribution of heavy metals, stable isotope ratios $(\delta 13 \mathrm{C}$ and $\delta 15 \mathrm{~N}$ ) and risk assessment of fish from the Yellow River Estuary, China." Chemosphere 208:731-739. doi: https://doi.org/10.1016/j.chemosphere.2018.06.028.

Liu, H., J. Yang, and J. Gan. 2010. "Trace Element Accumulation in Bivalve Mussels Anodonta woodiana from Taihu Lake, China." Archives of Environmental Contamination and Toxicology 59 (4):593601. doi: 10.1007/s00244-010-9521-6.

Liu, M., J. Chen, X. Sun, Z. Hu, and D. Fan. 2019. "Accumulation and transformation of heavy metals in surface sediments from the Yangtze River estuary to the East China Sea shelf." Environmental Pollution 245:111-121. doi: https://doi.org/10.1016/i.envpol.2018.10.128.

Losi, M. E., C. Amrhein, and W. T. Frankenberger. 1994. "Environmental Biochemistry of Chromium." In Reviews of Environmental Contamination and Toxicology, edited by George W. Ware, 91-121. New York, NY: Springer New York.

Łuszczek-Trojnar, E., E. Drąg-Kozak, and W. Popek. 2013. "Lead accumulation and elimination in tissues of Prussian carp, Carassius gibelio (Bloch, 1782), after long-term dietary exposure, and 
depuration periods." Environmental Science and Pollution Research 20 (5):3122-3132. doi: 10.1007/s11356-012-1210-8.

Malik, N., A. K. Biswas, T. A. Qureshi, K. Borana, and R. Virha. 2009. "Bioaccumulation of heavy metals in fish tissues of a freshwater lake of Bhopal." Environmental Monitoring and Assessment 160 (1):267. doi: 10.1007/s10661-008-0693-8.

MOH. 2012. China's Ministry of Health. Maximum levels of contaminants in seafood. GB2762-2012.

Nagarajan, R., M. P. Jonathan, Priyadarsi D. Roy, M. V. Prasanna, and A. Elayaraja. 2014. "Enrichment pattern of leachable trace metals in roadside soils of Miri City, Eastern Malaysia." Environmental Earth Sciences 72 (6):1765-1773. doi: 10.1007/s12665-014-3080-5.

Ouattara, A. A., K. M. Yao, K. C. Kinimo, and A. Trokourey. 2020. "Assessment and bioaccumulation of arsenic and trace metals in two commercial fish species collected from three rivers of Côte d'Ivoire and health risks." Microchemical Journal 154:104604. doi: https://doi.org/10.1016/i.microc.2020.104604.

Pedlar, R. M., and J. F. Klaverkamp. 2002. "Accumulation and distribution of dietary arsenic in lake whitefish (Coregonus clupeaformis)." Aquatic Toxicology 57 (3):153-166. doi: https://doi.org/10.1016/S0166-445X(01)00197-7.

Ploetz, D. M., B. E. Fitts, and T. M. Rice. 2007. "Differential Accumulation of Heavy Metals in Muscle and Liver of a Marine Fish, (King Mackerel, Scomberomorus cavalla Cuvier) from the Northern Gulf of Mexico, USA." Bulletin of Environmental Contamination and Toxicology 78 (2):134-137. doi: 10.1007/s00128-007-9028-7.

Pourang, N., C. A. Richardson, and M. S. Mortazavi. 2010. "Heavy metal concentrations in the soft tissues of swan mussel (Anodonta cygnea) and surficial sediments from Anzali wetland, Iran." Environmental Monitoring and Assessment 163 (1):195-213. doi: 10.1007/s10661-009-0827-7.

Prabakaran, K., R. Nagarajan, S. Eswaramoorthi, A. Anandkumar, and F. Merlin Franco. 2019. "Environmental significance and geochemical speciation of trace elements in Lower Baram River sediments." Chemosphere 219:933-953. doi: https://doi.org/10.1016/i.chemosphere.2018.11.158.

Rahman, M. S., A. H. Molla, N. Saha, and A. Rahman. 2012. "Study on heavy metals levels and its risk assessment in some edible fishes from Bangshi River, Savar, Dhaka, Bangladesh." Food Chemistry 134 (4):1847-1854. doi: https://doi.org/10.1016/i.foodchem.2012.03.099.

Rao, L. M., and G. Padmaja. 2000. "Bioaccumulation of heavy metals in M. cyprinoids from the harbour waters of Visakhapatnam." Bulletin of Pure and Applied Science 19(A) (2):77-85.

Ravera, O., R. Cenci, G. M. Beone, M. Dantas, and P. Lodigiani. 2003. "Trace element concentrations in fresh water mussels and macrophytes as related to those in their environment." Journal of Limnology 62 (1):61-70.

Rejomon, G., M. Nair, and T. Joseph. 2010. "Trace metal dynamics in fishes from the southwest coast of India." Environmental Monitoring and Assessment 167 (1):243-255. doi: 10.1007/s10661-0091046-y.

Reynders, H., L. Bervoets, M. Gelders, W. M. De Coen, and R. Blust. 2008. "Accumulation and effects of metals in caged carp and resident roach along a metal pollution gradient." Science of The Total Environment 391 (1):82-95. doi: https://doi.org/10.1016/j.scitotenv.2007.10.056.

Sarma, K., A. A. Kumar, G. George, P. K. Pandian, S. D. Roy, and R. C. Srivastava. 2013. "Impact of coastal pollution on biological, biochemical and nutritional status of edible oyster in Phoenix Bay Jetty and North Wandoor of Andaman." Indian Journal of Animal Sciences 83 (3):321-325.

Singh, A. K., S. I. Hasnain, and D. K. Banerjee. 1999. "Grain size and geochemical partitioning of heavy metals in sediments of the Damodar River - a tributary of the lower Ganga, India." Environmental Geology 39 (1):90-98. doi: 10.1007/s002540050439. 
Sivaperumal, P., T. V. Sankar, and P. G. Viswanathan Nair. 2007. "Heavy metal concentrations in fish, shellfish and fish products from internal markets of India vis-a-vis international standards." Food Chemistry 102 (3):612-620. doi: https://doi.org/10.1016/i.foodchem.2006.05.041.

Skoric, S., Z. Visnjić-Jeftic, I. Jaric, V. Djikanovic, B. Mickovic, M. Nikcevic, and M. Lenhardt. 2012. "Accumulation of 20 elements in great cormorant (Phalacrocorax carbo) and its main prey, common carp (Cyprinus carpio) and Prussian carp (Carassius gibelio)." Ecotoxicology and Environmental Safety 80:244-251. doi: https://doi.org/10.1016/j.ecoenv.2012.03.004.

Song, B., M. Lei, T. Chen, Y. Zheng, Y. Xie, X. Li, and D. Gao. 2009. "Assessing the health risk of heavy metals in vegetables to the general population in Beijing, China." Journal of Environmental Sciences 21 (12):1702-1709. doi: https://doi.org/10.1016/S1001-0742(08)62476-6.

Song, Y., J. Ji, Z. Yang, X. Yuan, C. Mao, R. L. Frost, and G. A. Ayoko. 2011. "Geochemical behavior assessment and apportionment of heavy metal contaminants in the bottom sediments of lower reach of Changjiang River." CATENA 85 (1):73-81. doi: https://doi.org/10.1016/j.catena.2010.12.009.

Staniskiene, B., P. Matusevicius, R. Budreckiene, and K. A. Skibniewska. 2006. "Distribution of Heavy Metals in Tissues of Freshwater Fish in Lithuania." Polish Journal of Environmental Studies 15 (4):585-591.

Tao, Y., Z. Yuan, H. Xiaona, and M. Wei. 2012. "Distribution and bioaccumulation of heavy metals in aquatic organisms of different trophic levels and potential health risk assessment from Taihu lake, China." Ecotoxicology and Environmental Safety 81:55-64. doi: https://doi.org/10.1016/j.ecoenv.2012.04.014.

Terra, B. F., F. G. Araújo, C. F. Calza, R. T. Lopes, and T. P. Teixeira. 2008. "Heavy Metal in Tissues of Three Fish Species from Different Trophic Levels in a Tropical Brazilian River." Water, Air, and Soil Pollution 187 (1):275-284. doi: 10.1007/s11270-007-9515-9.

USEPA. 2000. Guidance for Assessing Chemical Contaminant Data for Use in Fish Advisories, Risk Assessment and Fish Consumption Limit. Washington, DC, USA: Office of Science and Technology and Office of Water.

USEPA. 2015. "Human health risk assessment, risk-based screening table, regional screening level (RSL) summary table ". http://semspub.epa.gov/work/03/2218434.pdf.

Varol, M., G. K. Kaya, and A. Alp. 2017. "Heavy metal and arsenic concentrations in rainbow trout (Oncorhynchus mykiss) farmed in a dam reservoir on the Firat (Euphrates) River: Risk-based consumption advisories." Science of The Total Environment 599-600:1288-1296. doi: https://doi.org/10.1016/j.scitotenv.2017.05.052.

Viarengo, A., D. Lowe, C. Bolognesi, E. Fabbri, and A. Koehler. 2007. "The use of biomarkers in biomonitoring: A 2-tier approach assessing the level of pollutant-induced stress syndrome in sentinel organisms." Comparative Biochemistry and Physiology Part C: Toxicology \& Pharmacology 146 (3):281-300. doi: https://doi.org/10.1016/j.cbpc.2007.04.011.

Wang, H., Q. Wu, W. Hu, B. Huang, L. Dong, and G. Liu. 2018. "Using multi-medium factors analysis to assess heavy metal health risks along the Yangtze River in Nanjing, Southeast China." Environmental Pollution 243:1047-1056. doi: https://doi.org/10.1016/i.envpol.2018.09.036.

Wang, R. L., R. H. Sun, and D. Y. Wu. 2015. "Distribution and risk assessment of heavy metals in crucian carp (Carassius auratus) of Luan River." Asian journal of Ecotoxicology (In Chinese) 10 (6):229237.

Wang, W. X., and P. S. Rainbow. 2008. "Comparative approaches to understand metal bioaccumulation in aquatic animals." Comparative Biochemistry and Physiology Part C: Toxicology \& Pharmacology 148 (4):315-323. doi: https://doi.org/10.1016/i.cbpc.2008.04.003. 
Wang, X., Z. Chu, F. Zha, S. Liu, G. Liu, and Z. Dong. 2015. "Determination of Heavy Metals in Water and Tissues of Crucian Carp (Carassius auratus Gibelio) Collected from Subsidence Pools in Huainan Coal Fields (China)." Analytical Letters 48 (5):861-877. doi: 10.1080/00032719.2014.961606.

Wang, Y., P. Chen, R. Cui, W. Si, Y. Zhang, and W. Ji. 2010. "Heavy metal concentrations in water, sediment, and tissues of two fish species (Triplohysa pappenheimi, Gobio hwanghensis) from the Lanzhou section of the Yellow River, China." Environmental Monitoring and Assessment 165 (1):97-102. doi: 10.1007/s10661-009-0929-2.

WHO. 1989a. Heavy metals environmental aspects. Environmental Health Criteria. Geneva, Switzerland.

WHO. 1989b. WHO, 1989. Heavy Metals Environmental Aspects. Environmental Health Criteria. Geneva, Switzerland.

Yang, Z., H. Wang, Y. Saito, J. D. Milliman, K. Xu, S. Qiao, and G. Shi. 2006. "Dam impacts on the Changjiang (Yangtze) River sediment discharge to the sea: The past 55 years and after the Three Gorges Dam." Water Resources Research 42 (4). doi: 10.1029/2005wr003970.

Yi, Y. J., C. Tang, Ti. Yi, Z. Yang, and S. H. Zhang. 2017. "Health risk assessment of heavy metals in fish and accumulation patterns in food web in the upper Yangtze River, China." Ecotoxicology and Environmental Safety 145:295-302. doi: https://doi.org/10.1016/j.ecoenv.2017.07.022.

Yi, Y. J., and S. H. Zhang. 2012. "Heavy metal (Cd, Cr, Cu, Hg, Pb, Zn) concentrations in seven fish species in relation to fish size and location along the Yangtze River." Environmental Science and Pollution Research 19 (9):3989-3996. doi: 10.1007/s11356-012-0840-1.

Yi, Y., Z. Wang, K. Zhang, G. Yu, and X. Duan. 2008. "Sediment pollution and its effect on fish through food chain in the Yangtze River." International Journal of Sediment Research 23 (4):338-347. doi: https://doi.org/10.1016/S1001-6279(09)60005-6.

Yi, Y., Z. Yang, and S. Zhang. 2011. "Ecological risk assessment of heavy metals in sediment and human health risk assessment of heavy metals in fishes in the middle and lower reaches of the Yangtze River basin." Environmental Pollution 159 (10):2575-2585. doi: https://doi.org/10.1016/j.envpol.2011.06.011.

YRYCC. 2013. Yangtze River Yearbook Compile Committee In Yangtze River Yearbook. Yangtze River Yearbook Society of Changjiang Water Resources.

Yuan, Q., P. Wang, C. Wang, J. Chen, X. Wang, S. Liu, and T. Feng. 2019. "Metals and metalloids distribution, source identification, and ecological risks in riverbed sediments of the Jinsha River, China." Journal of Geochemical Exploration 205:106334. doi: https://doi.org/10.1016/i.gexplo.2019.106334.

Zeng, H., and J. Wu. 2013. "Heavy metal pollution of lakes along the mid-lower reaches of the Yangtze River in China: intensity, sources and spatial patterns." International Journal of Environmental Research and Public Health 10 (3):793-807. doi: 10.3390/ijerph10030793.

Zhong, W., Y. Zhang, Zi. Wu, R. Yang, X. Chen, J. Yang, and L. Zhu. 2018. "Health risk assessment of heavy metals in freshwater fish in the central and eastern North China." Ecotoxicology and Environmental Safety 157:343-349. doi: https://doi.org/10.1016/i.ecoenv.2018.03.048.

Zhou, Q., J. Zhang, J. Fu, J. Shi, and G. Jiang. 2008. "Biomonitoring: An appealing tool for assessment of metal pollution in the aquatic ecosystem." Analytica Chimica Acta 606 (2):135-150. doi: https://doi.org/10.1016/j.aca.2007.11.018.

Zubcov, E., N. Zubcov, A. Ene, and L. Biletchi. 2012. "Assessment of copper and zinc levels in fish from freshwater ecosystems of Moldova." Environmental Science and Pollution Research 19 (6):22382247. doi: 10.1007/s11356-011-0728-5. 
Table 1. Morphometric measures of the studied Prussian carp and bivalve species from the

\section{Zhenjiang city}

\begin{tabular}{|c|c|c|c|c|c|c|}
\hline Species & $\begin{array}{c}\text { English/ } \\
\text { Chinese } \\
\text { name }\end{array}$ & Length $(\mathrm{cm})$ & Weight (g) & Habitat & Feeding nature & Climate \\
\hline Carassius gibelio & $\begin{array}{c}\text { Prussian } \\
\text { Crap }\end{array}$ & $17.9 \pm 0.45$ & $130.21 \pm 7.84$ & Benthic & $\begin{array}{c}\text { Omnivores (algae, } \\
\text { molluscs, worms, other } \\
\text { crustaceans, fungi, } \\
\text { bacteria, fishes and } \\
\text { detritus) }\end{array}$ & \multirow{2}{*}{$\begin{array}{c}\text { Tropical } \\
\quad \& \\
\text { Sub- } \\
\text { tropical }\end{array}$} \\
\hline $\begin{array}{l}\text { Sinanodonta } \\
\text { woodiana }\end{array}$ & $\begin{array}{l}\text { Chinese } \\
\text { pond } \\
\text { mussel }\end{array}$ & $10.23 \pm 0.68$ & $86.49 \pm 15.77$ & Benthic & $\begin{array}{c}\text { Filter Feeders } \\
\text { (planktons and algae) }\end{array}$ & \\
\hline
\end{tabular}

Table 2. Elements accumulation in various organs of the Prussian carp and Bivalve

\begin{tabular}{|l|l|l|}
\hline \multicolumn{1}{|c|}{ Species } & \multicolumn{1}{|c|}{ Tissue } & \multicolumn{1}{c|}{ Order } \\
\hline \multirow{4}{*}{ Carassius gibelio } & Viscera & $\mathrm{Zn}>\mathrm{Mn}>\mathrm{Cu}>\mathrm{As}>\mathrm{Cr}>\mathrm{Pb}>\mathrm{Cd}>\mathrm{Hg}$ \\
\cline { 2 - 3 } & Gill & $\mathrm{Zn}>\mathrm{Mn}>\mathrm{Cu}>\mathrm{As}>\mathrm{Cr}>\mathrm{Hg}>\mathrm{Cd}>\mathrm{Pb}$ \\
\cline { 2 - 3 } & Skin & $\mathrm{Zn}>\mathrm{Mn}>\mathrm{Cu}>\mathrm{As}>\mathrm{Cr}>\mathrm{Hg}>\mathrm{Pb}>\mathrm{Cd}$ \\
\cline { 2 - 3 } & Muscle & $\mathrm{Mn}>\mathrm{Zn}>\mathrm{Cu}>\mathrm{As}>\mathrm{Cr}>\mathrm{Pb}>\mathrm{Cd}>\mathrm{Hg}$ \\
\hline \multirow{5}{*}{ Sinanodonta woodiana } & Mantle & $\mathrm{Mn}>\mathrm{Zn}>\mathrm{Cu}>\mathrm{As}>\mathrm{Cr}>\mathrm{Pb}>\mathrm{Cd}>\mathrm{Hg}$ \\
\cline { 2 - 3 } & Foot Muscle & $\mathrm{Mn}>\mathrm{Zn}>\mathrm{Cu}>\mathrm{As}>\mathrm{Cr}>\mathrm{Pb}>\mathrm{Cd}>\mathrm{Hg}$ \\
\cline { 2 - 3 } & Gill & $\mathrm{Mn}>\mathrm{Zn}>\mathrm{Cu}>\mathrm{As}>\mathrm{Cr}>\mathrm{Pb}>\mathrm{Cd}>\mathrm{Hg}$ \\
\cline { 2 - 3 } & Gonad &
\end{tabular}


Table 3. Comparison of elemental concentrations $\left(\mu \mathrm{g} \mathrm{g}^{-1}\right.$ dry weight) in the muscle tissues of Prussian carp and Bivalve species

\section{from the Zhenjiang, City with the other regions}

\begin{tabular}{|c|c|c|c|c|c|c|c|c|c|}
\hline Location & Sample & $\mathbf{C u}$ & $\mathbf{Z n}$ & Mn & $\mathrm{Cr}$ & Cd & $\mathbf{P b}$ & $\mathrm{Hg}$ & As \\
\hline Present study & Carassius gibelio Gill & 2.662 & 247.409 & 16.455 & 0.491 & 0.010 & 0.003 & 0.016 & 0.515 \\
\hline Present Study & Carassius gibelio Muscle & 2.255 & 63.721 & 1.230 & 0.950 & 0.011 & 0.174 & 0.454 & 0.823 \\
\hline Present Study & Carassius gibelio Skin & 2.869 & 71.848 & 3.755 & 0.579 & 0.009 & 0.151 & 0.284 & 0.717 \\
\hline Present Study & Carassius gibelio Viscera & 7.016 & 344.266 & 8.570 & 0.660 & 0.056 & 0.157 & 0.051 & 0.699 \\
\hline Present study & Sinanodonta woodianaMantle & 3.683 & 156.254 & 359.550 & 0.616 & 0.074 & 0.404 & 0.014 & 1.915 \\
\hline Present Study & Sinanodonta woodiana Foot muscle & 2.826 & 102.096 & 227.900 & 0.542 & 0.034 & 0.278 & 0.016 & 2.232 \\
\hline Present Study & Sinanodonta woodiana Gill & 8.399 & 292.756 & 507.500 & 0.689 & 0.133 & 0.512 & 0.032 & 3.926 \\
\hline Present Study & Sinanodonta woodiana Gonad & 4.627 & 183.251 & 384.350 & 0.739 & 0.135 & 0.368 & 0.022 & 3.520 \\
\hline Huainan China ${ }^{1}$ & Carassius auratus Gibelio Muscle & $1.14-1.77$ & $8.63-10.5$ & - & - & $0.005-0.01$ & $0.12-0.36$ & - & - \\
\hline Huainan China $^{1}$ & Carassius auratus Gibelio Gill & $1.70-352$ & $12.32-19.23$ & - & - & $0.032-0.073$ & $0.80-1.43$ & - & - \\
\hline Huainan China $^{1}$ & Carassius auratus Gibelio Viscera & $4.67-12.81$ & $16.15-24.53$ & - & - & $0.13-0.165$ & $0.52-1.84$ & - & - \\
\hline Yangtze River, China $^{2}$ & Carassius auratus auratus Muscle & 1.09 & 9.40 & & 0.33 & 0.17 & 0.89 & 0.014 & 0.019 \\
\hline${\text { Yangtze River, } \text { China }^{3}}$ & Carassius auratus Muscle & 0.93 & 6.445 & - & 0.19 & 0.132 & 0.811 & 0.0079 & - \\
\hline Eastern China ${ }^{4}$ & Carassius carassius Muscle & 0.89 & 19.80 & 0.54 & 2.98 & 0.04 & 0.12 & - & 0.17 \\
\hline Luan River, China ${ }^{5}$ & Carassius auratus Muscle & 5.07 & 57.40 & - & 6.67 & 0.05 & 1.12 & - & 0.10 \\
\hline Taihu Lake, China $^{6}$ & Carassius auratus Muscle & 1.89 & 180.00 & - & 0.387 & 0.013 & 0.287 & - & - \\
\hline Taihu Lake, China $^{6}$ & Carassius auratus Gonad & 13.61 & 249.00 & - & 1.038 & 0.01 & 0.201 & - & - \\
\hline Xiang River $^{7}$ & Carassius auratus & $0.19-23.13$ & $4.69-87.28$ & $0.22-7.241$ & - & $0.021-0.093$ & $0.056-0.183$ & - & $0.042-0.082$ \\
\hline $\operatorname{Iran}^{8}$ & Carassius auratus Gibelio Muscle & 7.40 & 19.40 & - & 0.70 & 0.29 & 1.30 & - & - \\
\hline $\operatorname{Iran}^{8}$ & Carassius auratus Gibelio Gill & 11.90 & 31.30 & - & 1.00 & 0.40 & 3.10 & - & - \\
\hline India $^{9}$ & L. rohita and C. idella Muscle & 0.59 & 1.88 & - & 0.58 & 0.427 & 1.32 & 0.14 & - \\
\hline Nigera $^{10}$ & Freshwater fishes (4 species) & 3.01 & 63.10 & 53.02 & - & 0.8 & 10.01 & - & - \\
\hline Bangladesh $^{11}$ & Freshwater fishes (7 species) & $8.33-43.18$ & $42.83-418$ & $9.43-51.17$ & $0.47-2.07$ & $0.09-0.87$ & $1.76-10.27$ & - & $1.97-6.24$ \\
\hline Hooghly River, India ${ }^{12}$ & Esturaine fishes & $16.22-47.97$ & $12.13-44.74$ & - & ND-3.89 & $0.62-1.20$ & $12.40-19.96$ & - & - \\
\hline Korea $^{13}$ & Anodonta woodiana & - & - & - & - & 0.024 & 0.195 & 0.052 & 3.545 \\
\hline Poland $^{14}$ & Anodonta sp. & 57.50 & 119.20 & 821.50 & - & 0.90 & 49.8 & - & - \\
\hline Liuyang River, China $^{15}$ & Anodonta woodiana & 25.99 & 581.30 & 12179.42 & 2.88 & 0.95 & 5.82 & - & 13.97 \\
\hline Taihu Lake, China ${ }^{16}$ & Anodonta woodiana & 18.50 & 1252 & 11886 & - & 23.10 & 2.8 & - & 15.00 \\
\hline Danube River, Austria $^{17}$ & Anodonta sp. & $0.90-12.70$ & $71-862$ & - & - & $0.1-1.13$ & $0.1-21.3$ & - & - \\
\hline Italy $^{18}$ & Anodonta cygnea & 34.00 & 642.00 & 11258 & 0.40 & 10.00 & 23.00 & - & 13.00 \\
\hline $\operatorname{Iran}^{19}$ & Anodonta cygnea & 0.209 & - & - & - & 0.117 & 0.255 & - & - \\
\hline
\end{tabular}

${ }^{1}$ Wang et al. (2015), ${ }^{2}$ Yi et al. (2011), ${ }^{3}$ Yi et al. (2012), ${ }^{4}$ Zhong et al. (2018), ${ }^{5}$ Wang et al. (2015), ${ }^{6}$ Chi el al. (2007), ${ }^{7}$ Jia et al. (2017), ${ }^{8}$ Ebrahimpour et al. (2011), ${ }^{9}$ Malik et al. (2009), ${ }^{10}$ Asuquo et al. (2004), ${ }^{11}$ Rahman et al. (2012), ${ }^{12}$ De et al. (2010), ${ }^{13}$ Habte et al. (2015), ${ }^{14}$ Krolak and Zdanowski (2001), ${ }^{15}$ Jia et al. (2018), ${ }^{16}$ Liu et al. (2010), ${ }^{17}$ Gundacker (2000), ${ }^{18}$ Ravera et al. (2003), ${ }^{19}$ Pourang et al. (2010). 
Table 4. Estimated daily intakes (EDI $\mu \mathrm{g} \mathrm{kg} \mathrm{body} \mathrm{wt}^{-1} \mathrm{day}^{-1}$ wet weight) of metals by consuming Prussian carp and Bivalve

species

\begin{tabular}{|l|c|c|c|c|c|c|c|c|}
\hline \multicolumn{1}{|c|}{ Species } & Cu & Zn & Mn & Cr & Cd & Pb & Hg & As \\
\hline Carassius gibelio Gill & 0.879 & 81.645 & 5.430 & 0.162 & 0.003 & 0.001 & 0.005 & 0.170 \\
\hline Carassius gibelio Muscle & 0.744 & 21.028 & 0.406 & 0.313 & 0.004 & 0.057 & 0.150 & 0.271 \\
\hline Carassius gibelio Skin & 0.947 & 23.710 & 1.239 & 0.191 & 0.003 & 0.050 & 0.094 & 0.236 \\
\hline Carassius gibelio Viscera & 2.315 & 113.608 & 2.828 & 0.218 & 0.019 & 0.052 & 0.017 & 0.231 \\
\hline Sinanodonta woodianaMantle & 1.215 & 51.564 & 118.652 & 0.203 & 0.025 & 0.133 & 0.004 & 0.632 \\
\hline Sinanodonta woodiana Foot muscle & 0.933 & 33.692 & 75.207 & 0.179 & 0.011 & 0.092 & 0.005 & 0.737 \\
\hline Sinanodonta woodiana Gill & 2.772 & 96.609 & 167.475 & 0.227 & 0.044 & 0.169 & 0.010 & 1.296 \\
\hline Sinanodonta woodiana Gonad & 1.527 & 60.473 & 126.836 & 0.244 & 0.045 & 0.121 & 0.007 & 1.161 \\
\hline PTDI & 500 & 1000 & 140 & 3 & 1 & 3.57 & 0.23 & 2.14 \\
\hline
\end{tabular}

PTDI Provisional tolerable daily intake suggested by Joint FAO/WHO committee on Food Additives (JECFA 1999a). The PTDI value of Cr was based on the reference dose (RfD) of Cr (VI) established by US Environmental Protection Agency (2011), For Hg and As adpated from Bhupander and Mukherjee (2011) 
Table 5. Indicating HI for muscle consumption calculated at mean ingestion and subsistence rates for Prussian carp and

\section{Bivalve species}

\begin{tabular}{|c|c|c|c|c|c|c|c|c|c|c|c|c|c|c|c|c|}
\hline Sample & $\mathbf{C u}^{\mathrm{a}}$ & $\mathrm{Cu}^{\mathrm{b}}$ & $\mathbf{Z n}^{\mathrm{a}}$ & $\mathbf{Z n}^{\mathrm{b}}$ & $\mathbf{M n}^{\mathrm{a}}$ & $\mathbf{M n}^{\mathrm{b}}$ & $\mathrm{Cr}^{\mathrm{a}}$ & $\mathbf{C r}^{b}$ & $\mathbf{C d}^{\mathrm{a}}$ & $\mathbf{C d}^{\mathrm{b}}$ & $\mathbf{P b}^{\mathrm{a}}$ & $\mathbf{P b}^{\mathrm{b}}$ & $\mathbf{H g}^{\mathrm{a}}$ & $\mathbf{H g}^{\mathrm{b}}$ & $\mathbf{A s}^{\mathrm{a}}$ & $\mathbf{A s}^{\mathrm{b}}$ \\
\hline Carassius gibelio Gill & 0.025 & 0.115 & 0.095 & 0.432 & 0.004 & 0.018 & 0.000 & 0.001 & 0.005 & 0.022 & 0.022 & 0.099 & 0.674 & $3.075^{*}$ & $1.222^{*}$ & $5.577^{*}$ \\
\hline Carassius gibelio Muscle & 0.030 & 0.135 & 0.368 & $1.678^{*}$ & 0.052 & 0.239 & 0.000 & 0.001 & 0.004 & 0.020 & 0.000 & 0.002 & 0.024 & 0.110 & 0.764 & $3.489^{*}$ \\
\hline Carassius gibelio Skin & 0.078 & 0.357 & 0.511 & $2.334^{*}$ & 0.027 & 0.125 & 0.000 & 0.001 & 0.025 & 0.115 & 0.020 & 0.090 & 0.075 & 0.344 & $1.038^{c}$ & $4.736^{*}$ \\
\hline Carassius gibelio Viscera & 0.032 & 0.146 & 0.107 & 0.487 & 0.012 & 0.055 & 0.000 & 0.001 & 0.004 & 0.017 & 0.019 & 0.086 & 0.422 & $1.926^{*}$ & $1.065^{*}$ & $4.859^{*}$ \\
\hline Sinanodonta woodianaMantle & 0.041 & 0.187 & 0.232 & $1.060^{*}$ & $1.145^{*}$ & $5.224^{*}$ & 0.000 & 0.001 & 0.033 & 0.151 & 0.050 & 0.230 & 0.020 & 0.092 & $2.844^{*}$ & $12.982^{*}$ \\
\hline $\begin{array}{l}\text { Sinanodonta woodiana Foot } \\
\text { muscle }\end{array}$ & 0.031 & 0.144 & 0.152 & 0.692 & 0.726 & $3.312^{*}$ & 0.000 & 0.001 & 0.015 & 0.070 & 0.035 & 0.158 & 0.024 & 0.111 & $3.316^{*}$ & $15.135^{*}$ \\
\hline Sinanodonta woodiana Gill & 0.094 & 0.427 & 0.435 & $1.985^{*}$ & $1.616^{*}$ & $7.374^{*}$ & 0.000 & 0.001 & 0.059 & 0.270 & 0.064 & 0.291 & 0.047 & 0.214 & $5.833^{*}$ & $26.6222^{*}$ \\
\hline Sinanodonta woodiana Gonad & 0.052 & 0.235 & 0.272 & $1.243^{*}$ & $1.224^{*}$ & $5.585^{*}$ & 0.000 & 0.001 & 0.060 & 0.275 & 0.046 & 0.210 & 0.033 & 0.149 & $5.229^{*}$ & $23.866^{*}$ \\
\hline
\end{tabular}

${ }^{\mathrm{a}} 0.0312 \mathrm{~kg} / \mathrm{day}$ (mean ingestion rate) ${ }^{\mathrm{b}}\left(0.1424 \mathrm{~kg} / \mathrm{day}\right.$ (subsistence ingestion rate)); ${ }^{*} \mathrm{HI}>1$, adverse health effects are excepted to occur.

Table 6. Maximum Permissible Limit (MPL) of trace metals in fish muscles ( $\mu \mathrm{g} \mathrm{g}^{-1}$ wet weight) according to National and

International Guideline values.

\begin{tabular}{lcccccccc}
\hline \multicolumn{1}{c}{ Standards } & $\mathbf{C u}$ & $\mathbf{C r}$ & $\mathbf{P b}$ & $\mathbf{C d}$ & $\mathbf{Z n}$ & $\mathbf{M n}$ & $\mathbf{H g}$ & As \\
\hline WHO (1989a) & 30 & 50 & 2 & 1 & 100 & $0.5-1$ & - & \\
CFHC (1994) & 50 & 2 & 0.5 & 0.1 & 50 & - & 0.5 & 0.1 \\
FAO (1983) & 30 & - & 0.5 & 0.5 & 40 & - & 0.5 & 1.4 \\
HKG (1987) & - & - & - & - & - & - & 0.5 & 2.3 \\
USEPA (2000) & 120 & 8 & 4 & 2 & 120 & - & - & - \\
EC (2014) & - & - & 0.3 & 0.5 & 30 & - & - & - \\
FSSAI (2015) & - & - & 0.3 & 0.3 & - & - & - & -
\end{tabular}

WHO - World Health Organization; CFHC - Chinese Food Health Criterion; FAO - Food and Agricultural Organization; HKG - Hong Kong Government

regulation; USEPA - United States Environmental Protection Agency; EC - European Commission; FSSAI - Safety, Food, Standards Authority of India 


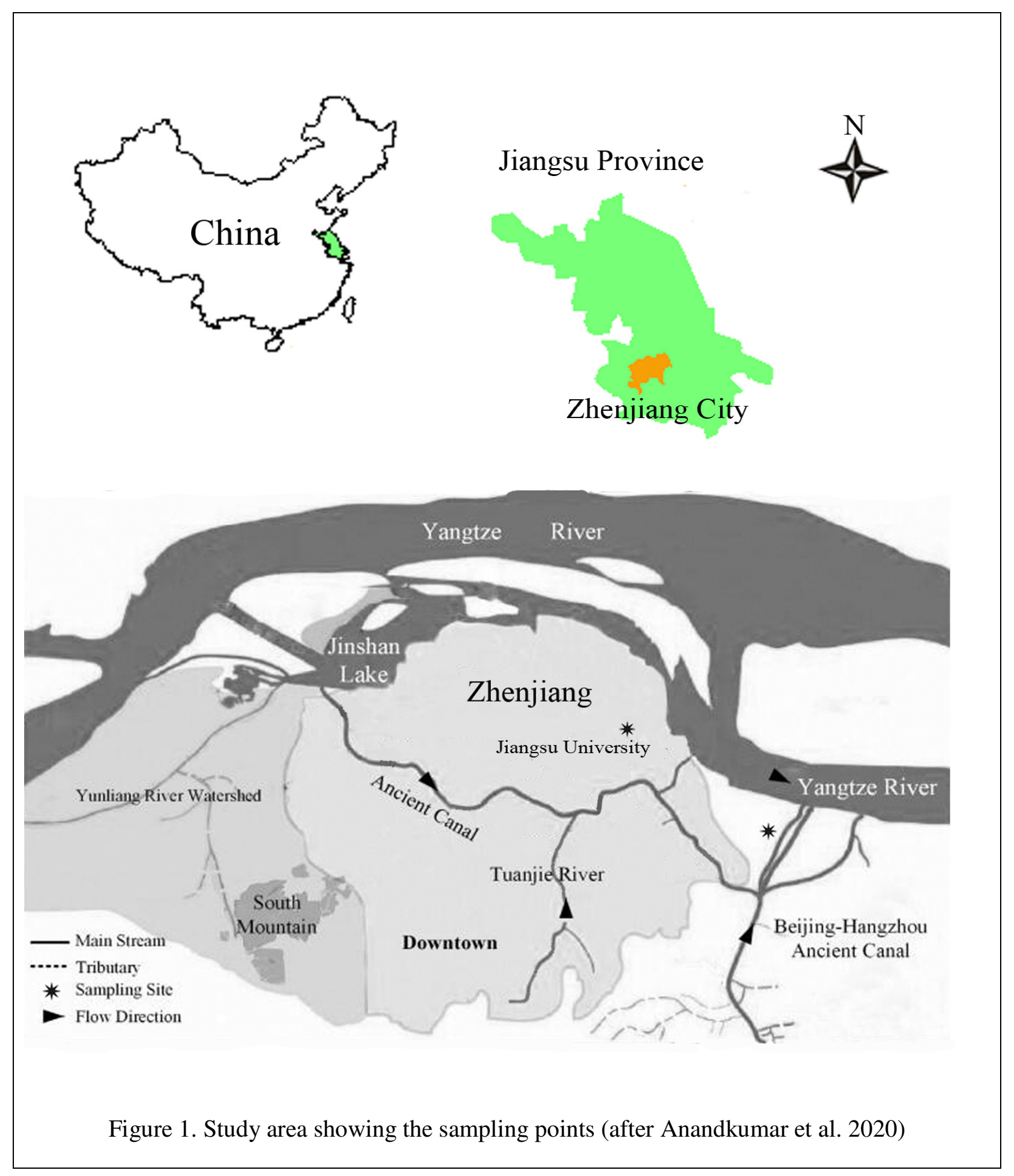

